\title{
PERBANDINGAN WASIAT \\ DALAM PERSPEKTIF KOMPILASI HUKUM ISLAM (KHI) D AN BURGERLIJK WETBOEK (BW)
}

\author{
Moh. Syamsul Mu'arif \\ Institut Agama Islam Bani Fattah Jombang, Indonesia \\ E-mail: syamsul.4121f@gmail.com
}

\begin{abstract}
Testament is one of the aspects of civil law which belongs to Islamic marriage laws. On social issues, the problems will not be underestimated as a social construct that maps the public perception of religious and nationalist groups. Government officials administering the State provide a solution in the form of implementation of the postulate of the will in the presence of Burgerlijk Wetboek (BW) as a guideline Kompilasi Islamic Law (KHI) to guide religious groups. Charge two guidelines and be appreciated by pros and cons in the social domain. By considering several postulations texts and findings of thought in both the conservative position, modern or liberal, can find common ground that can be justified academically in relation to maqâsid Syarìah. In comparative studies, social of maslahab match point which can be used as a guide for each group. This study concluded that there was no significant difference in the two postulations. This is evidenced in the level of definition, limits will part as well as the validity and cancellation will. Thus, according to the researchers, the application will be it based on the postulation BW and KHI, is still based on the social good.
\end{abstract}

Keywords: Testament, Kompilasi Islamic Law, Burgerlijk Wetboek 


\section{Pendahuluan}

Wasiat merupakan bagian dari hukum kewarisan. Pengertian wasiat ialah pernyataan kehendak oleh seseorang mengenai apa yang akan dilakukan terhadap hartanya setelah meninggal dunia. ${ }^{1}$ Wasiat dari segi etimologi berasal dari Bahasa Arab, yaitu wasiyyah yang artinya pelepasan, yakni pelepasan terhadap harta peninggalan yang dilakukan seseorang sewaktu masih hidup, untuk dilaksanakan setelah meninggal dunia. ${ }^{2}$ Adapun pengertian wasiat dari segi terminologi ialah pernyataan atau perkataan seseorang kepada orang lain untuk memberikan hartanya, membebaskan hutang atau memberikan manfaat suatu barang miliknya setelah meninggal dunia.

Ulama Syafi'iyah mendefinisikan wasiat sebagai amal sedekah dengan suatu hak yang disandarkan pada suatu keadaan setelah mati, baik cara menyandarkan itu dengan ucapan atau tidak. Sehingga dengan adanya wasiat akan memungkinkan seseorang yang mempunyai harta lebih untuk menyisihkan sebagian harta tersebut dan tidak dimasukkan ke dalam jumlah harta peninggalan yang akan dibagi kepada ahli warisnya. Maka setelah mempertimbangkan kebutuhan ahli waris, sebagian harta tersebut akan diberikan pada pihak lain yang masih membutuhkan, seperti kaum kerabat yang miskin sedangkan ia bukan tergolong ahli waris yang mendapatkan warisan.

Merupakan kewajiban moral bagi seseorang untuk memenuhi hak orang lain atau kerabatnya, karena orang tersebut telah banyak berjasa kepadanya atau membantu usaha dan kehidupannya, sedangkan ia bukan termasuk keluarga yang memperoleh bagian harta warisan. Berdasarkan hal-hal tersebut di atas, maka wasiat berfungsi sebagai amal kebajikan yang bisa membersihkan diri dari beban dosa, disamping bertujuan untuk membantu saudara-saudaranya yang membutuhkan, atau untuk kepentingan umum yang diridlai oleh Allah swt.

\section{Wasiat Dalam Perspektif KHI}

Wasiat menurut Kompilasi Hukum Islam ialah pemberian suatu benda dari pewaris kepada orang lain atau lembaga yang akan berlaku setelah pewaris meninggal dunia. Hal ini sesuai dengan bunyi pasal 171 huruf (f) Kompilasi Hukum Islam. Definisi menurut kompilasi Hukum

\footnotetext{
${ }^{1}$ Sajuti Thalib, Hukum Kewarisan Islam di Indonesia, (Jakarta: Sinar Grafika, 2000),104.

2 Muhammad Hasbi al-Shiddiqie, Fiqih Mawaris, (Semarang: Pustaka Riski Putra, 1999), 273.
} 
Islam tersebut mengandung pengertian bahwa agar ada wasiat harus ada pewasiat, penerima wasiat dan benda yang diwasiatkan.

Sedangkan klausul wasiat ialah suatu pemberian yang baru akan berlaku (mempunyai kekuatan hukum tetap) setelah yang memberikan meninggal dunia. Dengan demikian, wasiat menurut Kompilasi Hukum Islam merupakan pemberian yang digantungkan pada kejadian tertentu, baik pemberian tersebut dengan atau tanpa persetujuan dari yang diberi wasiat. ${ }^{3}$ Kompilasi Hukum Islam mengambil dasar hukum wasiat dari alQur'an dan hadits Nabi Muhammad saw, antara lain:

Pertama, Al-Qur'an QS. al-Baqarah: 180-181:
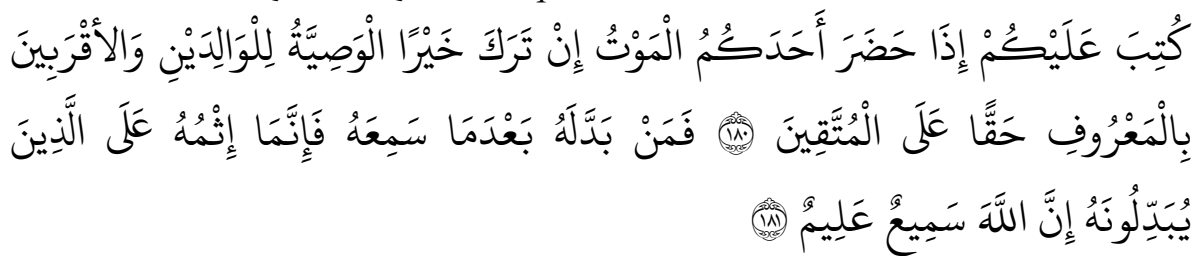

Artinya: "Diwajibkan atas kamu apabila seseorang diantara kamu kedatangan (tandatanda)maut, jika ia meninggalkan harta yang banyak, berwasiat untuk ibu dan bapak dan karib kerabatnya secara ma'ruf. Ini adalab kewajiban atas orangorang yang bertaqwa. Maka barang siapa yang mengubah suatu wasiat itu setelah ia mendengarnya, maka sesungguhnya dosanya adalah bagi orangorang yang mengubahnya. Sesunggubnya Allab Maha Mendengar lagi Maha Mengetabui.” (QS. al-Baqarah: 180-181)

Berdasarkan ayat tersebut di atas menunjukkan bahwa apabila seseorang dalam keadaan marâdu al-maut dan mempunyai harta yang berlebih, maka dianjurkan untuk berwasiat terhadap kerabat-kerabatnya yang sangat membutuhkan. Disisi lain bagi pihak yang mendengarkan atau menerima.

Wasiat, diharuskan bersikap jujur dan adil. Oleh karena jika orangorang tersebut dengan sengaja mengubah isi wasiat, maka hal ini akan menghalangi tercapainya maksud baik dari pewasiat dan akan menanggung dosa atas perbuatannya tersebut.

Pada hakekatnya wasiat itu semacam akad. Oleh karena itu sebaiknya wasiat disaksikan oleh dua orang saksi yang adil dan beragama Islam. Akan tetapi bila dalam keadaan terpaksa atau dalam perjalanan jauh yang tidak memungkinkan adanya saksi yang beragama Islam, maka diperbolehkan mengambil saksi yang berlainan agama. Maksud dari

3 Amir Hamzah dan A. Rachmad Budiono, Hukum Kewarisan dalam Kompilasi Hukum Islam, (Malang: IKIP, 1994), 66. 
adanya saksi dalam ayat tersebut di atas diharapkan dalam perkara wasiat mudah diselesaikan jika ada persengketaan di kemudian hari setelah orang yang berwasiat meninggal dunia.

Kedua, Hadis riwayat Bukhari dan Muslim:

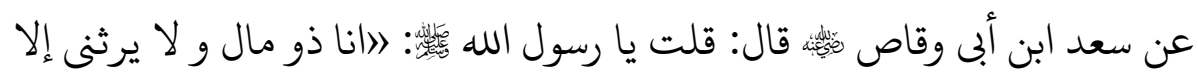
إبنة لم واحدة أفأتصدق بثلثى مالى قال: لا. قلت: أفأتصدق بشطره قال: لا. قلت: أفأتصدق بثلثه الثلث، و الثلث كثير. إنك أن تذر ورثتك أغنيأ خير من أن تذرهم عالة يتكففون الناسبا.

Artinya: "Dari Sa'ad ibn Abi Waqash Beliau berkata: Saya berkata: Ya Rasulullah, saya orang yang mempunyai harta yang banyak (kaya) dan tidak ada yang mewarisi saya kecuali seorang anak perempuan. Apakah saya sedekabkan dua pertiga harta saya? Beliau menjawab: Jangan. Saya bertanya lagi: Apakah saya sedekabkan separubnya? Beliau menjawab: Jangan. Saya bertanya lagi: Apakah saya sedekabkean sepertiganya? Beliau bersabda: Sepertiga. Sepertiga itu banyak. Sesunggubnya kamu tinggalkan abli warismu dalam keadaan kaya lebih baik daripada kamu meninggalkan mereka dalam keadaan miskin yang akan meminta-minta kepada orang lain.

Berdasarkan hadits tersebut di atas mempunyai pengertian bahwa bagi setiap orang yang akan berwasiat sebaiknya mendahulukan kepentingan ahli warisnya. Oleh karena meninggalkan ahli waris dalam keadaan yang berkecukupan adalah lebih baik daripada meninggalkan mereka dalam keadaan miskin. Hadits tersebut memberikan pemahaman bahwa wasiat sebagai pelaksana ibadah untuk investasi kehidupan akhirat, akan memberikan manfaat bagi kepentingan orang lain atau masyarakat pada umumnya.

Ketiga, Ijmâ'. Kaum muslimin sepakat bahwa tindakan wasiat merupakan syari'at Allah dan Rasul-Nya. Ijma' yang demikian didasarkan pada ayatayat al-Qur'an dan hadits seperti yang dikutip di atas.

\section{Rukun dan Syarat Wasiat}

a) Orang yang Berwasiat.

Ada dua syarat kumulatif agar seseorang dapat mewasiatkan sebagian harta bendanya. Dua syarat tersebut adalah; telah berumur sekurang-kurangnya 21 tahun; dan berakal sehat. Syarat lainnya adalah 
wasiat tersebut harus dibuat tanpa ada paksaan dari orang lain. ${ }^{4} \mathrm{Hal}$ ini dinyatakan dalam pasal 194 ayat (1) Kompilasi Hukum Islam.

Kompilasi Hukum Islam menggunakan batasan umur untuk menentukan bahwa seseorang talah mampu melakukan perbuatanperbuatan hukum, yaitu sekurangkurangnya berumur 21 tahun. Umumnya anak-anak di Indonesia, pada usia di bawah 21 tahun dipandang belum atau tidak mempunyai hak kepemilikan karena masih menjadi tanggungan kedua orang tuanya, kecuali apabila sudah dikawinkan. Menurut Amir Hamzah dan A. Rachmad Budiono, batasan umur tersebut harus diikuti perkecualian, yakni orang-orang yang telah melangsungkan perkawinan. Hal ini dikarenakan pada pasal 15 Kompilasi Hukum Islam menyebutkan untuk kemaslahatan keluarga dan rumah tangga, perkawinan hanya boleh dilakukan calon mempelai yang telah mencapai umur yang ditetapkan dalam undangundang nomor 7 tahun 1974 pasal (7), yakni calon suami sekurangkurangnya berumur 19 tahun dan calon istri sekurang-kurangnya mencapai umur 16 tahun. Setelah seseorang melangsungkan perkawinan, meskipun belum mencapai umur 21 tahun harus dianggap telah dewasa, yang berarti cakap melakukan perbuatan hukum, termasuk membuat wasiat.

Agar seseorang dapat menyatakan kehendak wasiatnya, maka ia harus berakal sehat. Syarat ini logis dan harus disertakan, sebab jika tidak akan sulit diketahui apakah seseorang benar-benar ingin mewasiatkan hartanya atau tidak.

b) Penerima Wasiat.

Sesuai bunyi pasal 171 huruf (f) dapat diketahui bahwa penerima wasiat adalah; orang; dan lembaga. Pasal 196 menegaskan bahwa dalam wasiat baik secara tertulis maupun secara lisan harus disebutkan dengan tegas siapa atau siapa-siapa atau lembaga apa yang ditunjuk akan menerima harta benda yang diwasiatkan.

Pada dasarnya setiap orang, kecuali pewasiatnya sendiri dapat menjadi subyek penerima wasiat. Ada beberapa perkecualian mengenai hal ini, sebagaimana tercantum dalam pasal 195 ayat (3), pasal 207 dan pasal 208 mengenai orang-orang yang tidak dapat diberi wasiat.

Pasal 195 ayat (3) menyebutkan wasiat kepada ahli waris hanya berlaku bila disetujui oleh semua ahli waris.

\footnotetext{
${ }^{4}$ Ibid., 66-67.
} 
Pasal 207 menyebutkan wasiat tidak diperbolehkan pada orang yang melakukan pelayanan perawatan bagi seseorang dan kepada orang yang memberi tuntunan kerohanian sewaktu ia menderita sakit hingga meninggalnya, kecuali ditentukan dengan tegas dan jelas untuk membalas jasanya.

Pasal 208 menjelaskan wasiat tidak berlaku bagi notaris dan saksisaksi pembuat akta tersebut.

Kompilasi Hukum Islam telah mengambil jalan tengah dari perselisihan pendapat apakah ahli waris dapat menerima wasiat atau tidak.

Orang yang sakit lazimnya tidak berdaya, baik mental maupun fisik. Oleh karena itu mudah sekali timbul rasa simpati pada diri orang yang sakit tersebut terhadap orang-orang yang menolongnya. Dalam keadaan yang demikian mudah sekali timbul rasa simpatik pada diri orang yang akan berwasiat. Untuk mencegah berlebih-lebihannya perwujudan perasaan yang demikian itu, diadakan pembatasanpembatasan hukum, agar pihak-pihak lain (misalnya ahli waris) tidak dirugikan. Ketentuan sebagaimana yang tercantum dalam pasal 207 dilatarbelakangi konsep bahwa tidak tepat untuk mengatakan perasaan si sakit yang demikian itu sebagai "tidak berakal sehat", akan tetapi hal ini memang bias dikatakan tidak berakal sehat sehingga perlu diadakan suatu pembatasan. Namun demikian, yang agaknya mengaburkan penafsiran itu adalah klausula yang tercantum dalam pasal tersebut, yaitu: "kecuali ditentukan dengan jelas dan tegas untuk membalas jasa."

Alasan Notaris dan saksi-saksi yang berkaitan dengan pembuatan akta wasiat tidak diperbolehkan menerima wasiat, dikarenakan kekhawatiran mereka akan menyalahgunakan kedudukannya apabila diperbolehkan menerima wasiat. Misalnya mengubah atau mengganti isi surat wasiat untuk kepentingannya sendiri.

c) Barang Wasiat.

Pasal 171 huruf (f) menyebutkan "suatu benda" sebagai sesuatu yang dapat diwasiatkan. Kompilasi Hukum Islam membedakan benda yang dapat diwasiatkan ke dalam benda bergerak dan benda tidak bergerak. Hal ini sesuai dengan pasal 200 yang menyatakan bahwa harta wasiat yang berupa barang tak bergerak, bila karena suatu sebab yang sah mengalami penyusutan atau kerusakan yang terjadi sebelum pewasiat meninggal dunia, maka penerima wasiat hanya akan menerima harta yang tersisa. 
Wasiat juga bisa berupa hasil atau pemanfaatan suatu benda tertentu. Hal ini sesuai dengan pasal 198 Kompilasi Hukum Islam yang menyebutkan: wasiat yang berupa hasil dari suatu benda ataupun pemanfaatan suatu benda harus diberi jangka waktu tertentu. Pembatasan jangka waktu yang dimaksudkan dalam Kompilasi Hukum Islam ini untuk memudahkan tertib administrasi.

Benda yang diwasiatkan mempunyai syarat yang melekat pada hubungan hukum antara pewasiat dengan benda yang diwasiatkan yaitu benda tersebut merupakan hak dari pewasiat. Oleh karena wasiat merupakan pemindahan hak, maka yang berhak memindahkan hak benda tersebut haruslah orang yang memilikinya.

d) Redaksi Wasiat.

Pada dasarnya wasiat dapat dilaksanakan dengan menggunakan redaksi (sighat) yang jelas atau sarîh dengan kata wasiat, dan bisa juga dilakukan dengan kata-kata samaran (ghairu sarîh). Wasiat bisa dilakukan dengan cara tertulis dan tidak memerlukan jawaban (qabûl) penerimaan secara langsung. Dalam konteks kehidupan sekarang ini, cara-cara tersebut di atas tentu akan mengurangi kepastian hukumnya.

Oleh karena itu perlu diatur agar wasiat tersebut dapat dibuktikan secara otentik, yaitu dilakukan secara lisan dihadapan dua orang saksi, atau tertulis dihadapan dua orang saksi atau dihadapan Notaris berdasarkan pasal 195 ayat (1). Menurut A. Rachmad Budiono, dua orang saksi tersebut merupakan jumlah minimal yang diperbolehkan. Artinya dapat saja wasiat dilakukan dihadapan lebih dari dua orang saksi.

Apabila wasiat ditujukan kepada ahli waris, maka persetujuan para ahli waris lainnya dapat dibuat secara lisan maupun tertulis. Persetujuan secara lisan maupun tertulis yang bukan akta otentik harus dilakukan terhadap dua orang saksi. Persetujuan seperti ini dilakukan dihadapan seorang Notaris.

Dalam pasal 203 ayat (1) dikatakan: Apabila surat wasiat dalam keadaan tertutup, maka penyimpanannya dilakukan di tempat Notaris yang membuatnya atau di tempat lain, termasuk surat-surat yang ada hubungannya dengan wasiat tersebut. Upaya penyaksian wasiat baik melalui saksi biasa atau Notaris sebagai pejabat resmi, dimaksudkan agar realisasi wasiat setelah pewasiat meninggal dunia dapat berjalan dengan lancar.

e) Pembatasan Wasiat.

Pada dasarnya wasiat hanya diperbolehkan sebanyak-banyaknya sepertiga dari harta warisan kecuali apabila semua ahli waris 
menyetujuinya. Jumlah benda yang boleh diwasiatkan tersebut sesuai dengan hadits Rasulullah saw. Yang diriwayatkan oleh Sa'ad ibn Abi Waqash. Batasan wasiat ini dimaksudkan untuk melindungi kepentingan ahli waris yang lain agar mereka tetap memperoleh harta warisan. Oleh karena itu apabila pewasiat hendak mewasiatkan hartanya lebih dari sepertiga harta warisan dan maksud ini disetujui oleh ahli waris yang lain maka wasiat yang seperti itu sah dilakukan. Hal ini diatur dalam pasal 195 ayat (2) yang menyatakan bahwa wasiat hanya diperbolehkan sebanyak-banyaknya sepertiga dari harta warisan kecuali apabila semua ahli waris menyetujuinya. Sementara pasal 201 yang menegaskan apabila wasiat melebihi sepertiga dari harta warisan, sedangkan ahli waris yang lain tidak menyetujuinya, maka wasiat hanya dilakukan sampai batas sepertiga saja.

f) Pembatalan Wasiat.

1) Gugurnya Wasiat.

Menurut pasal 197 ayat (1) apabila calon penerima wasiat berdasarkan putusan hakim yang telah mempunyai kekuatan hukum tetap dihukum karena; Pertama, Disalahkan telah membunuh atau mencoba membunuh atau menganiaya berat si pewasiat. Kedua, Dipersalahkan secara memfitnah telah mengajukan pengaduan bahwa pewasiat telah melakukan kejahatan yang diancam hukuman lima tahun penjara atau hukuman yang lebih berat. Ketiga, Dipersalahkan dengan kekerasan atau ancaman mencegah pewasiat untuk membuat atau mencabut atau merubah wasiat untuk kepentingan calon penerima wasiat.

Diantara banyak faktor yang menyebabkan batalnya wasiat tersebut, pembunuhan terhadap pewasiat merupakan faktor terberat untuk menghalangi seseorang menerima wasiat. Menurut Imam Abu Yusuf berwasiat kepada orang yang telah membunuh pewasiat, baik wasiat itu diizinkan oleh ahli waris maupun tidak adalah tidak sah. Hal ini didasarkan pada sabda Rasulullah saw. Yang mengatakan: 'tidake ada wasiat bagi si pembunub'. Pendapat inilah yang dianut oleh Kompilasi Hukum Islam. Sedangkan tiga sebab batalnya wasiat yang tercantum dalam pasal 197 huruf (b), (c) dan (d) diambil berdasarkan pertimbangan kemaslahatan.

Disamping hal-hal tersebut, pasa 197 ayat (2) Kompilasi Hukum Islam juga menegaskan bahwa wasiat menjadi batal apabila orang yang ditunjuk untuk menerima wasiat itu; Pertama, Tidak mengetahui adanya wasiat tersebut. Kedua, Mengetahui adanya wasiat tersebut tetapi dia menolak untuk menerimanya. Ketiga, 
Mengetahui adanya wasiat tersebut, tetapi tidak pernah menyatakan menerima atau menolak sampai ia meninggal sebelum meninggalnya si pewasiat.

Pada ayat 3 disebutkan bahwa wasiat akan menjadi batal apabila barang yang diwasiatkan tersebut musnah.

2) Cabutnya Wasiat.

Pada dasarnya wasiat dapat dicabut kembali apabila calon penerima wasiat belum menyatakan persetujuannya atau menyatakan persetujuan tetapi menariknya kembali. Hal ini dinyatakan dalam pasal 199 ayat (1) Kompilasi Hukum Islam yang menyebutkan pewasiat dapat mencabut wasiatnya selama calon penerima wasiat belum menyatakan persetujuannya atau sudah menyatakan persetujuannya tetapi kemudian menariknya kembali. Dengan demikian apabila calon penerima wasiat telah menyetujuinya atau tidak menarik kembali persetujuannya, maka suatu wasiat tidak dapat dicabut. Ketentuan tersebut menyatakan bahwa Kompilasi Hukum Islam memandang wasiat bukan merupakan perbuatan hukum sepihak, melainkan dua pihak sebagaimana layaknya suatu perjanjian. Suatu perjanjian hanya dapat dibatalkan apabila mendapat persetujuan dari kedua belah pihak

Pasal 199 ayat (2) Kompilasi Hukum Islam menegaskan bahwa pencabutan wasiat dapat dilakukan secara lisan dengan disaksikan oleh dua orang saksi atau tertulis dengan disaksikan oleh dua orang saksi atau berdasarkan akta Notaris bila wasiat terdahulu dibuat secara lisan. Apabila wasiat dibuat secara tertulis, maka hanya dapat dicabut dengan cara tertulis dengan disaksikan oleh dua orang saksi atau berdasarkan akta Notaris. Suatu wasiat yang dibuat berdasarkan akta Notaris maka hanya bisa dicabut berdasarkan akta Notaris juga.

\section{Wasiat Dalam Perspektif KUH Perdata}

a) Pengertian Wasiat.

Menurut KUH Perdata ada dua cara untuk mendapatkan warisan, yaitu; sebagai ahli waris menurut ketentuan Undang-undang, dan karena ditunjuk dalam surat wasiat (testament).

Cara yang pertama disebut ahli waris ab intestato sedangkan cara yang kedua disebut ahli waris secara testamentair. ${ }^{5}$

\footnotetext{
${ }^{5}$ Subekti, Pokok-Pokok Hukum Perdata, (Jakarta: Intermasa, 1994), 95.
} 
Testament ialah suatu pernyataan dari seseorang tentang apa yang dikehendaki setelah orang tersebut meninggal dunia, di mana isinya tidak boleh bertentangan dengan Undang-undang. ${ }^{6}$ Pasal $875 \mathrm{KUH}$ Perdata menyatakan bahwa suatu testament atau surat wasiat adalah suatu akta yang memuat pernyataan seseorang tentang apa yang dikehendaki agar terjadi setelah ia meninggal dunia, dan yang olehnya dapat dicabut kembali.

Berdasarkan pasal $875 \mathrm{KUH}$ Perdata tersebut dalam suatu testament terdapat beberapa unsur yang harus diperhatikan, antara lain:

Pertama, Testament merupakan suatu akta. Hal ini berarti suatu testament haruslah berbentuk tulisan yang dapat dibuat dengan akta otentik maupun akta di bawah tangan dan isinya berupa pernyataan atau kehendak dari pewasiat. ${ }^{7}$

Kedua, Suatu testamen berisi suatu pernyataan kehendak, yang berarti suatu tindakan hukum sepihak. Tindakan hukum sepihak adalah tindakan atau pernyataan dari seseorang yang sudah dianggap cukup untuk menimbulkan akibat hukum yang dikehendaki. Testament menimbulkan suatu perikatan, namun bukan suatu perjanjian yang mensyaratkan adanya kesepakatan di antara orang yang mengikatkan diri pada perjanjian tersebut. Karena tanpa adanya kesepakatan terlebih dahulu dari pihak yang diberi wasiatpun suatu testament sudah dianggap sah. ${ }^{8}$

Ketiga, Unsur selanjutnya adalah apa yang dikehendaki akan terjadi setelah meninggal dunia. Berarti bahwa suatu testament baru berlaku setelah pemberi wasiat telah meninggal dunia. Oleh sebab itu testament disebut juga dengan kehendak terakhir.

Keempat, Wasiat atau testament dapat dicabut kembali. Ketentuan digunakan untuk menetapkan apakah suatu tindakan hukum harus dibuat dalam bentuk surat wasiat atau cukup dengan bentuk lain. Pencabutan ini memberikan suatu pengertian bahwa tidak semua yang diinginkan oleh seseorang sebagaimana yang diletakkan dalam wasiatnya, juga diperbolehkan atau dapat dilaksanakan.

b) Syarat-Syarat Wasiat.

Pertama, Orang Yang Berwasiat. Pada pasal 897 KUH Perdata disebutkan bahwa para belum dewasa yang belum mencapai umur

\footnotetext{
6 Tamakiran, Asas-Asas Hukum Waris Menurut Tiga Sistem Hukum, (Bandung: Pionir Jaya), 28-29.

${ }^{7}$ Simanjuntak, Pokok-Pokok Hukum Perdata, (Jakarta: Djambatan, 1999) 267.

${ }^{8}$ J. Satrio, Hukum Waris, (Bandung: Alumni, 1992), 180.
} 
genap delapan belas tahun tak diperbolehkan membuat surat wasiat. Hal ini berarti seseorang dapat dikatakan dewasa dan dapat membuat surat wasiat apabila sudah mencapai umur delapan belas tahun, akan tetapi orang yang sudah menikah walaupun belum berumur delapan belas tahun diperbolehkan membuat surat wasiat. Karena kedewasaan seseorang akibat perkawinan sudah dianggap mempunyai kecakapan dalam pembuatan surat wasiat.

Mengenai kecakapan orang yang membuat surat wasiat atau testament adalah bahwa orang tersebut mampu berpikir secara normal atau berakal sehat. Sesuai dengan pasal 895 KUH Perdata yang menyebutkan untuk dapat membuat atau mencabut suatu surat wasiat seseorang harus mempunyai akal budinya. Sehingga seseorang yang kurang memiliki akal sehat ketika membuat surat wasiat, maka wasitanya tersebut tidak dapat diberikan akibat hukum atau dinyatakan batal. Pasal 895 KUH Perdata tersebut tidak memberikan wewenang kepada orang yang tidak memiliki akal sehat untuk melakukan perbuatan kepemilikan dengan surat wasiat.

Ketidaksehatan dari suatu akal pikiran dapat bersifat tetap seperti sakit gila, dan juga dapat bersifat hanya sementara seperti dalam keadaan mabuk, sakit panas atau demam yang sangat tinggi dan dibawah hipnose. Hal ini berarti jika seseorang dalam kondisi yang demikian membuat surat wasiat, maka keabsahan wasiatnya dapat ditentang oleh para ahli warisnya. ${ }^{9}$ Apabila seseorang yang sedang dalam keadaan tidak berakal sehat telah membuat surat wasiat kemudian setelah itu menjadi normal kembali dan masih hidup lama, maka jika tidak mengubah wasiatnya (ketika dalam keadaan normal tersebut) tetap tidak sah sebagaimana orang tersebut masih dalam keadaan tidak berakal sehat.

Kedua, Penerima Wasiat. Orang yang menerima suatu wasiat harus ada sewaktu orang yang berwasiat meninggal dunia (tertuang dalam pasal 899 KUH Perdata). Ketentuan ini bermaksud untuk menghindari ketidakpastian dari orang yang diberi wasiat dan menetapkan bahwa suatu wasiat gugur dalam hal pihak yang mendapatkan keuntungan (wasiat) meninggal terlebih dahulu.

Pasal 912 KUH Perdata menyebutkan bahwa mereka yang telah dihukum karena membunuh si yang mewariskan, lagipun mereka yang telah menggelapkan, membinasakan dan memalsu surat wasiatnya dan akhirnyapun mereka yang dengan paksaan atau kekerasan telah

\footnotetext{
${ }_{9}^{9}$ Oemar Salim, Dasar-Dasar Hukum Waris di Indonesia, (Jakarta: Bina Aksara, 1987), 38.
} 
mencegah si yang mewariskan tadi, akan mencabut atau mengubah surat wasaiatnya.

Ketiga, Benda Yang Diwasiatkan. Benda yang diwasiatkan sama halnya dengan benda yang diwariskan oleh orang yang meninggal dunia. Dalam hukum waris berlaku suatu asas bahwa hanya hak-hak dan kewajiban dalam lapangan hukum kekayaan harta benda saja yang dapat diwariskan ataupun diwasiatkan, yakni hanya meliputi hal-hal yang dapat dinilai dengan uang. Sehingga ahli waris menerima aktiva dan pasiva yang dimiliki oleh pewaris, yaitu menerima semua hak eigendom, menggantikan sebagai pemegang hak erfpacht, sebagai pihak yang berpiutang (kreditur) dan pihak yang berhutang (debitur).

Oleh karena itu terdapat hak dan kewajiban yang tidak beralih kepada ahli waris dan berakhir ketika pewaris atau pewasiat meninggal dunia, yakni hak dan kewajiban yang bersifat pribadi (privat), antara lain kekuasaan sebagai orang tua, perwalian, pengampuan dan pemberian nafkah. Hak vruchtgebruik atau perjanjian perburuhan dimana seseorang akan melakukan suatu pekerjaan dengan tenaganya sendiri, perjanjian perkongsian dagang, baik yang berbentuk maatscap (Perseroan) maupun yang berbentuk Firma.

c) Isi Surat Wasiat.

Pada dasarnya suatu wasiat atau testament berisi mengenai surat wasiat pengangkatan waris atau yang disebut dengan erfstelling dan surat wasiat hibah atau disebut dengan legaat.

1) Surat Wasiat Pengangkatan Waris.

Pengertian surat wasiat pengangkatan waris (erfstelling) terdapat dalam pasal $954 \mathrm{KUH}$ Perdata yang menyebutkan bahwa surat wasiat pengangkatan waris adalah suatu wasiat dengan mana si yang mewasiatkan, kepada seorang atau lebih, memberikan harta kekayaan yang akan ditinggalkannya apabila ia meninggal dunia baik seluruhnya atuapun sebagian, seperti misalnya setengah, sepertiganya. Berdasarkan pasal tersebut diatas dapat disimpulkan bahwa suatu erfsterling menunjuk seseorang atau beberapa orang menjadi "ahli waris" yang akan mendapatkan seluruh atau sebagian dari warisan. Orang yang ditunjuk dalam wasiat ini dinamakan testamentair erfgenaam. Orang yang memperoleh suatu erfsterlling mempunyai kedudukan seperti ahli waris abintestato, ${ }^{10}$ dalam arti

10 Ahli waris ab-intestato ialah ahli waris menurut ketentuan undang-undang, yaitu sanak keluarga dari orang yang meninggal dunia (saling mempunyai hubungan darah). Keluarga ini terdiri dari golongan pertama yang meliputi keturunan (anak, cucu dan 
bahwa keduanya (ahli waris ab-intestato dan erfsterlling) tidak hanya memperoleh hak-hak (aktiva) yang terdapat pada harta warisan, akan tetapi juga kewajiban-kewajiban (pasiva) atas harta warisan, misalnya membayar hutang dari orang yang berwasiat.

2) Surat Wasiat Hibah (legaat).

Pasal 957 KUH Perdata menyebutkan bahwa hibah wasiat adalah suatu penetapan wasiat yang khusus, dengan mana si yang mewasiatkan kepada seorang atau lebih memberikan beberapa barangnya dari suatu jenis tertentu, seperti misalnya segala barangbarang bergerak atau tak bergerak, atau memberikan hak pakai hasil atas seluruh atau sebagian harta peninggalannya. Berdasarkan pada pasal tersebut di atas dapat ditarik kesimpulan bahwa hibah wasiat atau legaat memberikan kepada seseorang atau beberapa orang; Satu atau beberapa orang tertentu; Seluruh benda dari satu jenis tertentu, misalnya benda bergerak dan benda tidak bergerak; dan Hak memungut hasil dari seluruh atau sebagian harta peninggalan pewaris.

Menurut pasal ini orang-orang yang memperoleh harta warisan berdasarkan hibah wasiat disebut legataris. Seorang legataris tidak mempunyai kedudukan ahli waris ab-intestato seperti halnya ahli waris erfsterling. Hal ini mengandung suatu pengertian bahwa seorang legataris menurut pasal $876 \mathrm{KUH}$ Perdata yang telah disebutkan dalam uraian terdahulu adalah penerima dengan alas hak khusus. Sehingga legataris tidak mempunyai hak saisine, hak hereditas petitio dan juga tidak bertanggung jawab secara yuridis atas pasiva orang yang berwasiat seperti berkewajiban menanggung hutang-hutang yang ditinggalkan oleh pewasiat. Legataris tersebut hanya berhak untuk menuntut penyerahan benda atau pelaksanaan hak yang diberikan kepadanya dari seluruh ahli waris.

3) Beban (last).

Suatu erfsterlling atau legaat dapat disertai dengan beban (last). Beban tersebut mengikat orang-orang yang ditunjuk dalam suatu erfsterlling dan legaat, yang berarti memberikan pada orang lain untuk menuntut suatu hak terhadap ahli waris pengangkatan wasiat (testamentair erfgenaam) atau seorang legataris secara perseorangan tidak terhadap boedel.

seterusnya), golongan kedua meliputi janda-janda dari orang yang meninggal dunia beserta keturunannya, golongan ketiga meliputi orang tua (ibu, bapak dan seterunya), serta golongan keempat yang terdiri dari keluarga sedarah lainnya. 
Pasal 958 KUH Perdata menyebutkan setiap hibah wasiat yang bersahaja dan tak bersyarat, memberi hak kepada mereka yang dihibahwasiati, semenjak hari meninggalnya si yang mewasiatkannya, untuk menuntut kebendaan yang dihibahwasiatkankannya, hak mana menurun kepada sekalian ahli waris atau pengganti haknya. Berdasarkan pasal tersebut kedudukan legataris hampir sama dengan seorang kreditur warisan terhadap ahli waris baik secara Undang-undang (ab-intestato) atau wasiat, karena mempunyai hak untuk menuntut benda yang diwasiatkan kepadanya.

Oleh karena berdasarkan hak saisine para ahli waris menerima seluruh aktiva dan pasiva pewaris, maka tuntutan ditujukan kepada para ahli waris, baik berdasarkan Undang-undang (ab-intestato) maupun ahli waris berdasarkan wasiat penunjukan waris (erfsterlling). Seperti yang sudah dijelaskan bahwa legaat membebani warisan seperti suatu hutang, maka ada kewajiban ahli waris selaku penanggung beban untuk memenuhi tuntutan legataris.

Adakalanya seorang legataris yang menerima beberapa benda diwajibkan memberi salah satu bendanya tersebut kepada orang lain yang ditunjuk dalam testament, dan pemberian suatu benda yang harus ditagih dari seorang legataris dinamakan sublegaat.Jadi apa yang dinamakan sublegaat sebenarnya adalah suatu beban. Jika beban tidak dipenuhi oleh seorang erfsterlling atau legataris, maka suatu erfsterlling atau legaat dapat dibatalkan atas permintaan pihak yang berkepentingan atau atas permintaan dari ahli waris yang lainnya.

d) Bentuk-bentuk surat wasiat.

Pelaksanaan kehendak terakhir dalam KUH Perdata harus dibuat sesuai dengan peraturan-peraturan yang telah ditetapkan oleh Undang-undang yang sifatnya memaksa. Salah satu kekhususan yang diatur yaitu mengenai orang yang hendak mewasiatkan sesuatu dapat menggunakan salah satu bentuk surat wasiat yang telah ditetapkan. Pasal 931 KUH Perdata menyebutkan bahwa suatu wasiat hanya boleh dinyatakan, baik dengan akta tertulis sendiri atau olographis, baik dengan akta umum, baik akta rahasia atau akta tertutup. 


\section{Analisis}

Hukum Islam, Kompilasi Hukum Islam dan KUH Perdata mendefinisikan wasiat sebagai pernyataan pemberian sesuatu yang disandarkan pada keadaan setelah meninggalnya orang yang berwasiat. Pengertian wasiat dalam hukum Islam ialah penyerahan harta secara sukarela dari seseorang kepada orang lain yang berlaku setelah orang tersebut meninggal dunia, baik yang diwasiatkan itu berupa benda ataupun manfaat. Sehingga sekalipun akad wasiat dibuat ketika orang yang berwasiat masih hidup, tetapi hukumnya berlaku setelah si pewasiat meninggal dunia.

Dalam Kompilasi Hukum Islam pasal 171 huruf (f) disebutkan bahwa wasiat adalah pemberian suatu benda dari pewaris kepada orang lain atau lembaga yang akan berlaku setelah pewaris meninggal dunia. Klausula dari wasiat yang terdapat dalam pasal tersebut adalah suatu pemberian yang baru akan berlaku (mempunyai kekuatan hukum tetap) apabila pewasiat telah meninggal dunia.

Begitu pula wasiat atau testament yang diatur dalam KUH Perdata, dalam pasal $875 \mathrm{KUH}$ Perdata menyebutkan surat wasiat atau testament adalah suatu akta yang berisi pernyataan seseorang tentang apa yang akan terjadi setelah meninggal dunia, dan yang olehnya dapat dicabut kembali.

Sehingga pada dasarnya dalam ketiga sistem hukum tersebut wasiat merupakan pemberian yang digantungkan pada kejadian meninggal dunianya orang yang berwasiat, baik pemberian tersebut dengan atau tanpa persetujuan dari yang diberi.

Pada umumnya seseorang berhak membuat suatu wasiat untuk seluruh harta peninggalan kepada siapapun yang dikehendaki. Akan tetapi Hukum Islam, Kompilasi Hukum Islam dan KUH Perdata juga mengatur tentang besarnya batasan wasiat yang dapat diberikan pada orang yang menerima wasiat

Hukum Islam dan Kompilasi Hukum Islam sama-sama membatasi besarnya wasiat hanya maksimal $1 / 3$ (sepertiga) dari seluruh harta warisan. Adapun jika melebihi $1 /{ }_{3}$ harta warisan, maka membutuhkan ijin dari para ahli waris. Hukum Islam mengambil ketentuan ini berdasarkan hadits yang diriwayatkan oleh Sa'ad ibn Abi Waqash yang diucapkan ketika Beliau sakit dan Rasulullah saw. mengunjunginya:

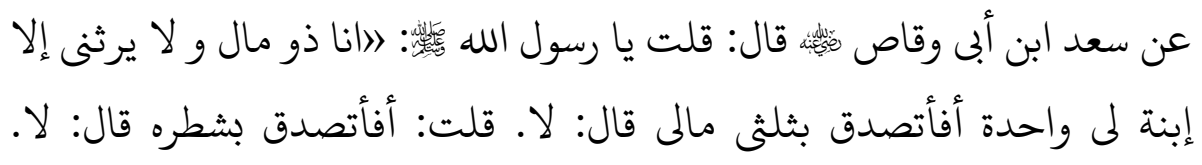




\section{قلت: أفأتصدق بثلثه الثلث, و الثلث كثير. إنك أن تذر ورثتك أغنيأ خير من

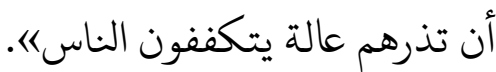

Artinya: 'Dari Sa'ad ibn Abi Waqash Beliau berkata: Saya berkata: Ya Rasulullah, saya orang yang mempunyai harta yang banyak (kaya) dan tidak ada yang mewarisi saya kecuali seorang anak perempuan. Apakah saya sedekabkan dua pertiga harta saya? Beliau menjawab: Jangan. Saya bertanya lagi: Apakah saya sedekahkan separubnya? Belian menjawab: Jangan. Saya bertanya lagi: Apakah saya sedekabkan sepertiganya? Beliau bersabda: Sepertiga. Sepertiga itu banyak. Sesunggubnya kamu tinggalkan abli warismu dalam keadaan kaya lebih baik daripada kamu meninggalkan mereka dalam keadaan miskin yang akan meminta-minta kepada orang lain."

Kompilasi Hukum Islam juga bersandar pada ketentuan hadits Sa'ad ibn Abi Waqash, yang tertuang dalam pasal 195 ayat (2) Kompilasi Hukum Islam yang menyatakan wasiat hanya diperbolehkan sebanyakbanyaknya $1 / 3$ (sepertiga) dari harta wasiat kecuali apabila semua ahli waris menyetujuinya.

Maksud dari adanya batasan wasiat ini adalah bertujuan untuk melindungi ahli waris yang bersangkutan dan mencegah praktek wasiat yang bisa merugikan mereka. Bagi setiap orang yang akan mewasiatkan sebagian hartanya, sebaiknya mendahulukan kepentingan ahli waris. Sebab meninggalkan ahli waris dalam keadaan berkecukupan adalah lebih baik daripada meninggalkan mereka dalam keadaan miskin.

Tujuan ketentuan batasan wasiat dalam Hukum Islam dan Kompilsai Hukum Islam ini dapat dilihat persamaannya dengan KUH Perdata, akan tetapi dalam konsep yang berbeda. Menurut KUH Perdata, pada dasarnya setiap orang mempunyai kebebasan untuk mengatur mengenai apa yang akan terjadi dengan harta kekayannya setelah meninggal dunia. Seorang pewaris juga mempunyai kebebasan untuk mencabut hak waris dari ahli warisnya. Akan tetapi untuk beberapa ahli waris ab intestato oleh Undang-undang diadakan bagian tertentu yang harus diterima mereka yang bagiannya dilindungi oleh hukum. Ahli waris ini dinamakan legitimaris, sedangkan bagiannya disebut legitime portie. Legitime portie adalah semua bagian dari harta warisan yang harus diberikan kepada ahli waris dalam garis lurus menurut Undang-undang, terhadap bagian mana orang yang meninggal dunia tidak diperbolehkan menetapkan sesuatu, baik selaku pembagian yang masih hidup maupun selaku wasiat. Ahli waris 
yang mempunyai bagian mutlak adalah ahli waris dalam garis lurus ke bawah dan garis lurus ke atas.

Menurut Hukum Islam, Kompilasi Hukum Islam dan KUH Perdata wasiat juga bisa batal dan dicabut. Pencabutan wasiat dapat dilakukan dengan tegas atau terang-terangan atau secara diam-diam. Mengenai pencabutan secara jelas dalam Hukum Islam dapat dilakukan dengan ucapan pewasiat yang mengatakan: "Saya batalkan wasiat yang telab saya akadkan pada Fulan". Apabila dilakukan secara diam-diam misalnya pewasiat menyembelih hewan yang telah diwasiatkan, menjualnya atau menghibahkannya pada orang lain. Kompilasi Hukum Islam menegaskan bahwa pencabutan wasiat dapat dilakukan secara lisan dengan disaksikan oleh dua orang saksi atau tertulis dengan disaksikan dengan dua orang saksi atau berdasarkan akta Notaris bila wasiat yang dahulu dibuat secara lisan.

Sedangkan dalam KUH Perdata pencabutan wasiat secara tegas dapat dilakukan dengan membuat surat wasiat baru atau dengan dibuatnya akta Notaris khusus yang mana diterangkan secara tegas bahwa surat wasiat yang terdahulu dicabut untuk seluruhnya.

\section{Kesimpulan}

Penelitian ini menghasilkan simpulan bahwa tidak terdapat perbedaan yang signifikan dalam dua postulasi tersebut. Hal ini dibuktikn dalam tataran definisi, batasan bagian wasiat serta keabsahan dan pembatalan wasiat. Sehingga, menurut peneliti, penerapan wasiat baik itu berlandaskan postulasi BW maupun KHI, masih tetap berlandaskan kemashlahatan sosial. 


\section{Daftar Pustaka}

Amir Hamzah dan A. Rachmad Budiono. Hukum Kewarisan dalam Kompilasi Hukum Islam. Malang: IKIP, 1994.

J. Satrio. Hukum Waris. Bandung: Alumni, 1992.

Shiddiqie (al), Muhammad Hasbi. Fiqih Mawaris,. Semarang: Pustaka Riski Putra, 1999.

Salim, Oemar. Dasar-Dasar Hukum Waris di Indonesia,. Jakarta: Bina Aksara, 1987.

Thalib, Sajuti. Hukum Kewarisan Islam di Indonesia. Jakarta: Sinar Grafika, 2000.

Simanjuntak. Pokok-Pokok Hukum Perdata. Jakarta: Djambatan, 1999.

Subekti. Pokok-Pokok. Hukum Perdata. Jakarta: Intermasa, 1994.

Tamakiran. Asas-Asas Hukum Waris Menurut Tiga Sistem Hukum. Bandung: Pionir Jaya, t.t. 